\title{
PENGARUH HEMOLISIS TERHADAP KADAR SERUM GLUTAMATE PYRUVATE TRANSAMINASE (SGPT) SEBAGAI SALAH SATU PARAMETER FUNGSI HATI
}

\author{
Hartono Kahar ${ }^{1}$ \\ 1) Prodi Ilmu Patologi Klinik, Fakultas Kedokteran, Universitas Airlangga \\ hartonokahar123@gmail.com
}

\begin{abstract}
Tangal Submit:

27 November 2017

Tanggal Review:

13 Desember 2017

Tanggal Publish Online:

22 Desember 2017

SGPT examination is one of the important checks on the state of a particular patient, for example, in patients with liver disease, hepatitis, and so forth. The other purpose is to detect the presence of liver damage. So there was an effect in the event of an increase in drop levels. And the serum circumstances that do not qualify, such as serum hemolysis, will greatly affect the actual levels of ALT. Based on the research background, the authors formulate the problem as follows: "Is there any effect of hemolysis on SGPT levels as one of the parameters of liver function?". The purpose of this study is to prove whether there is an influence of hemolysis on SGPT levels as one of the parameters of liver function. The sample was 20 samples and 20 samples of hemolysis hemolysis. Location and time of the research conducted at Muhammadiyah Hospital Clinical Laboratory Lamongan ie in January and July. Of the 20 samples analyzed, showing that levels higher than the hemolysis ALT SGPT levels no hemolysis. When the serum through lysis will experience a significant increase. To test the effect of hemolysis on SGPT levels paired t test was used because the data from this study with normally distributed. The results of a paired $t$ test analysis between serum hemolysis and no hemolysis on levels of serum ALT levels showed a significant value 0.00 thus $\mathrm{P}<0.05$ it can be concluded that there is no difference between the levels of ALT SGPT levels of hemolysis with hemolysis. That means there is the influence of hemolysis on SGPT levels as one of the parameters of liver function.
\end{abstract}

Keywords : : hemolysis, glutamate pyruvate transminase

\section{PENDAHULUAN}

Semakin pesatnya kemajuan teknologi laboratorium klinik telah banyak menambah jumlah dan jenis pemeriksaan laboratorium ke titik luar kemampuan kita untuk selalu dapat mengetahui penggunaan dan penafsirannya (Riyono, 2007). Pemeriksaan laboratorium yang bersamaan dengan riwayat kesehatan dan pemeriksaan fisik sering kali digunakan untuk memastikan diagnosis serta untuk memantau penyakit dan pengobatan.

Tes fungsi hati adalah sekelompok tes darah yang mengukur enzim atau protein tertentu di dalam darah anda. Tes fungsi hati umumnya digunakan untuk membantu men- 
deteksi, menilai dan memantau penyakit atau kerusakan hati. Pemeriksaan untuk fungsi hati biasanya tidak menentukan etiologi pasti penyakit hati. Pemeriksaan ini hanya sebagai petunjuk apakah hati normal atau sakit, dan apabila sakit, seberapa luas dan berat penyakitnya. Sebagai organ tubuh yang memiliki banyak fungsi penting, seperti menetralkan racun yang masuk ke dalam tubuh dan merombak nutrisi menjadi energi, hati memang sepatutnya selalu diperhatikan. Dalam pemeriksaan fungsi hati, ada beberapa parameter yang harus diperhatikan, yaitu SGOT (Serum Glutamat Oksaloasetat Transaminase) yang juga dinamakan AST (Aspartat Aminotransferase), SGPT (Serum Glutamat Piruvat Transaminase) yang juga dinamakan ALT (Alanin aminotransferase), bilirubin, gamma GT (Glutamat Transferase), ALP (Alkali Fosfatase), Cholinesterase, Total Protein (rasio albumin/globulin).

Hati merupakan organ padat terbesar yang terletak di rongga perut bagian kanan atas. Hati secara luas dilindungi oleh iga-iga. Organ ini mempunyai peran penting di dalam tubuh karena merupakan regulator dari semua metebolisme karbohidrat, protein dan lemak. Tempat sintesa dari berbagai komponen protein, pembekuan darah, kolesterol, ureum dan zat lain yg sangat vital. Selain itu, hati juga merupakan tempat pembentukan dan penyaluran asam empedu serta pusat pendetoksifikasi racun dan penghancuran (degradasi) hormon steroid seperti estrogen .
Enzim yang mengkatalisis pemindahan gugus amino secara reversibel antara asam amino dan alfa-keto ialah enzim aminotransferase yang sering disebut juga dengan enzim transaminase. Apabila terjadi gangguan fungsi hati, enzim aminotransferase di dalam sel akan masuk ke dalam peredaran darah, karena terjadi perubahan permeabilitas membran sel sehingga kadar enzim aminotransferase dalam darah akan meningkat (Widman, 1989).

Enzim aminotransferase yang paling sering dihubungkan dengan kerusakan sel hati adalah alanin aminotransferase (ALT) yang juga disebut serum glutamat piruvat transaminase (SGPT). Hati adalah satu satunya sel dengan konsentrasi SGPT yang tinggi, sedangkan ginjal, otot jantung, dan otot rangka mengandung kadar SGPT sedang. SGPT dalam jumlah yang lebih sedikit ditemukan di pankreas, paru, limpa, dan eritrosit. Dengan demikian, SGPT memiliki spesifitas yang relatif tinggi untuk kerusakan hati (Ronald, 2004). Apabila terjadi kerusakan sel, enzim akan banyak keluar ke ruang ekstra sel dan ke dalam aliran darah. Pengukuran konsentrasi enzim didalam darah dengan uji SGPT dapat memberikan informasi penting mengenai tingkat gangguan fungsi hati. Aktivitas SGPT di dalam hati dapat di deteksi meskipun dalam jumlah sangat kecil (Utami, 2009).

Hemolisis adalah pecahnya sel membran eritrosit, sehingga hemoglobin bebas 
ke dalam medium sekelilingnya (serum). Menurut Riswanto (2010), kerusakan membran sel eritrosit dapat disebabkan oleh antara lain mengeluarkan darah dari spuit tanpa melepas jarum terlebih dahulu. Penambahan larutan hipotonis, hipertonis kedalam darah, penurunan tekanan keras pada permukaan membran eritrosit, pemanasan dan pendinginan, rapuh karena ketuaan dalam sirkulasi darah. Apabila sel eitrosit pecah maka akan menyebabkan isi sel keluar, misalnya : enzim, elektrolit dan hemoglobin sehingga tampak merah muda sampai merah pada serum (Anonim a, 2008). Selama proses hemolisis terjadi perpindahan SGPT dari ruang intraseluler ke ekstraseluler. Sehingga dapat digunakan sebagai sarana untuk membantu diagnostik penyakit tertentu (Legawa,2011).

Berdasarkan dari uraian latar belakang di atas, penulis merumuskan permasalahan sebagai berikut: "Apakah ada pengaruh serum hemolisis terhadap kadar SGPT ?"

Adapun tujuan penelitian ini adalah sebagai berikut, Untuk mengetahui apakah ada pengaruh hemolisis terhadap kadar SGPT sebagai salah satu parameter fungsi hati, Menganalisa kadar SGPT tidak hemolisis. Menganalisa kadar SGPT hemolisis. Menganalisa adanya perbedaan kadar SGPT hemolisis dan tidak hemolisis.

\section{METODE PENELITIAN}

Jenis penilitian ini adalah penelitian eksperimental untuk mengetahui adanya pengaruh hemolisis terhadap kadar SGPT sebagai salah satu parameter fungsi hati.

Populasi dalam penelitian ini adalah pasien yang datang dengan pemeriksaan SGPT di Laboratorium Rumah Sakit Muhammadiyah Lamongan pada tanggal 26 - 29 Maret 2011. Sampel penelitian ini diambil setiap hari pada tanggal 26 - 29 Maret 2011 sampai didapatkan sejumlah 20 sampel. Dengan kriteria sampel sebagai berikut, Sampel didapatkan dari pasien yang datang ke Laboratorium Rumah Sakit Muhammadiyah Lamongan dengan pemeriksaan SGPT atas permintaan dokter pengirim. Dihindari hemolisis untuk sampel serum tidak hemolisis. Untuk jenis kelamin dan umur tidak dibatasi.

Lokasi penelitian ini dilaksanakan di Laboratorium Rumah Sakit Muhammadiyah Lamongan yaitu pada bulan Januari - Juli 2011. Waktu penelitian dilaksanakan selama bulan Januari - Juli 2011. Waktu pemeriksaan sampel dilaksanakan pada tanggal 26 - 29 Maret 2011.

Variabel bebas: Hemolisis adalah sampel berupa serum yang mendapat perlakuan dilisiskan yang ditandai dengan bebasnya hemoglobin ke dalam medium sekelilingnya (serum), yang memberikan warna merah pada sampel. Dilakukan dengan cara mengeluarkan darah dari spuit tanpa melepas jarum terlebih dahulu kemudian dimasukkan ke dalam tabung. dan tidak hemolisis, Tidak hemolisis adalah sampel berupa serum yang tidak mengandung sel-sel 
eritrosit, yang tidak mendapat perlakuan dilisiskan. Dilakukan dengan cara mengeluarkan darah dari spuit kemudian dimasukkan ke dalam tabung dengan cara melepas jarum lalu mengalirkan darah perlahan-lahan melalui dinding tabung.

. Variabel terikat: kadar SGPT kandungan SGPT dalam serum yang (diukur menggunakan alat TMS 1024i) dinyatakan dalam satuan U/L.

Data kadar SGPT dikumpulkan dengan cara melakukan pemeriksaan laboratorium di Rumah Sakit Muhammadiyah Lamongan dan mencatat data primer dari hasil pemeriksaan laboratorium kadar SGPT tidak hemolisis dan kadar SGPT hemolisis yang didapatkan dari langkah-langkah seperti di bawah ini. Setelah didapatkan data tersebut, kemudian disajikan dalam bentuk tabulasi data.

Metode kinetik untuk pengukuran aktivitas SGPT berdasarkan rekomendasi Expert Panel of the IFCC (International Federation of Clinical Chemistry).

Alat - alat pemeriksaan antara lain . TMS 1024i, Spuit 3cc, Kapas alkohol, Tourniquet, Kapas kering, Tabung reaksi, Rak tabung reaksi, Mikropipet $500 \mu 1$ dan $50 \mu 1$, blue tipe dan yellow tipe, Centrifuge. Bahan Pemeriksaan, Bahan yang digunakan dalam pemeriksaan ini adalah serum dari pasien yang datang ke laboratorium dengan pemeriksaan SGPT. Reagen Pemeriksaan Buffer, reagen enzym : Buffer TRIS (pH 7,5) 150 mmol/L, L- alanine $750 \mathrm{mmol} / \mathrm{L} \quad \mathrm{LDH} \quad \geq 1200 \mathrm{U} / \mathrm{L}$ Substrat, reagen starting : 2-oxoglutarate 90 $\mathrm{mmol} / \mathrm{L} \mathrm{NADH} 0,9 \mathrm{mmol} / \mathrm{L}$

\section{Prosedur Pemeriksaan}

\subsection{Persiapan Sampel}

a Pasien bisa diambil darahnya dan diperiksa kadar SGPTnya sewaktu-waktu.

b. Dilakukan pengambilan darah pada pasien dengan pemeriksaan SGPT.

c. Darah yang telah diambil dimasukkan ke dalam tabung reaksi. Disisakan $\pm 1 \mathrm{cc}$ darah untuk membuat serum hemolisis, didiamkan selama 10-15 menit di dalam spuit, setelah mulai membeku darah dari spuit tersebut dikeluarkan lewat ujung spuit tanpa melepas jarum. Diharapkan mendapatkan serum hemolisis akibat dari pecahnya sel darah merah.

d. Tabung yang berisi darah tersebut disentrifuge dengan kecepatan 2000 rpm selama 5 menit.

e. Setelah serum dan darah terpisah, segera diperiksa kadar SGPT.

\subsection{Pemeriksaan sampel}

1. Dipipet $500 \mu \mathrm{l}$ dan dimasukkan ke dalam cup sampel disposible.

2. Dan segera dianalisa.

Cara penggunaan TMS 1024i, adalah:

a. Pilih menu order, ketik nomor sesuai dengan cup sampel.

b. Pilih menu pasien, kemudian isi data sampel dengan data pasien meliputi, nomor sampel, nama pasien, jenis kelamin, pilih upload lalu exit. 
c. Pilih jenis pemeriksaan sesuai dengan permintaan dokter, kemudian pilih order lalu exit.

d. Pilih start dan biarkan alat bekerja selama 15 menit.

e. Catat hasil pemeriksaan dengan cara memilih menu review dan edit.

f. Kemudian dilakukan pencatatan hasil analisis.

Interpretasi hasil : Normal $\quad: 0-35 \mathrm{U} / \mathrm{L}$

Data yang diperoleh kemudian diuji dengan menggunakan uji Normalitas untuk mengetahui apakah data penelitian ini terdistribusi normal atau tidak. Kemudian dilanjutkan dengan uji $\mathrm{t}$ berpasangan untuk mengetahui pengaruh hemolisis terhadap kadar SGPT.

\section{HASIL PENELITIAN}

Penelitian dilakukan terhadap 20 sampel pada pasien yang melakukan pemeriksaan SGPT di Laboratorium Klinik Rumah Sakit Muhammadiyah Lamongan dan diukur juga kadar SGPT serum hemolisisnya kemudian didapatkan data sebagai berikut :

Tabel 1. Data Kadar SGPT Tidak Hemolisis dan Kadar SGPT Hemolisis

\begin{tabular}{|c|c|c|c|}
\hline \multirow{2}{*}{ No } & \multirow{2}{*}{$\begin{array}{c}\text { Kode } \\
\text { Sampel }\end{array}$} & \multicolumn{2}{|c|}{\begin{tabular}{c} 
Kadar SGPT (U/L) \\
\cline { 3 - 4 }
\end{tabular}} \\
\cline { 3 - 4 } & $\begin{array}{c}\text { Tidak } \\
\text { Hemolisis }\end{array}$ & Hemolisis \\
\hline 1 & PA & 72 & 76 \\
\hline 2 & PB & 21 & 24 \\
\hline 3 & PC & 63 & 66 \\
\hline 4 & PD & 58 & 61 \\
\hline 5 & PE & 25 & 27 \\
\hline 6 & PF & 34 & 37 \\
\hline 7 & PG & 52 & 55 \\
\hline 8 & PH & 10 & 13 \\
\hline 9 & PI & 16 & 18 \\
\hline
\end{tabular}

\begin{tabular}{|c|c|c|c|}
\hline 10 & PJ & 45 & 48 \\
\hline 11 & PK & 108 & 112 \\
\hline 12 & PL & 60 & 63 \\
\hline 13 & PM & 42 & 45 \\
\hline 14 & PN & 15 & 20 \\
\hline 15 & PO & 32 & 35 \\
\hline 16 & PP & 75 & 78 \\
\hline 17 & PQ & 55 & 56 \\
\hline 18 & PR & 46 & 47 \\
\hline 19 & PS & 43 & 45 \\
\hline 20 & PT & 86 & 89 \\
\hline \multicolumn{2}{|c|}{$\Sigma($ jumlah) } & 958 & 1015 \\
\cline { 2 - 4 }$(\bar{x}$ ) rata-rata & 47,9 & 50,75 \\
\hline
\end{tabular}

Sumber : data penelitian primer

Keterangan :

a. Interprestasi hasil : Normal : $0-35 \mathrm{U} / \mathrm{L}$

Data dari penelitian di atas dapat dibuat diagram batang untuk menggambarkan keadaan data penelitian seperti pada gambar 1 . berikut ini :

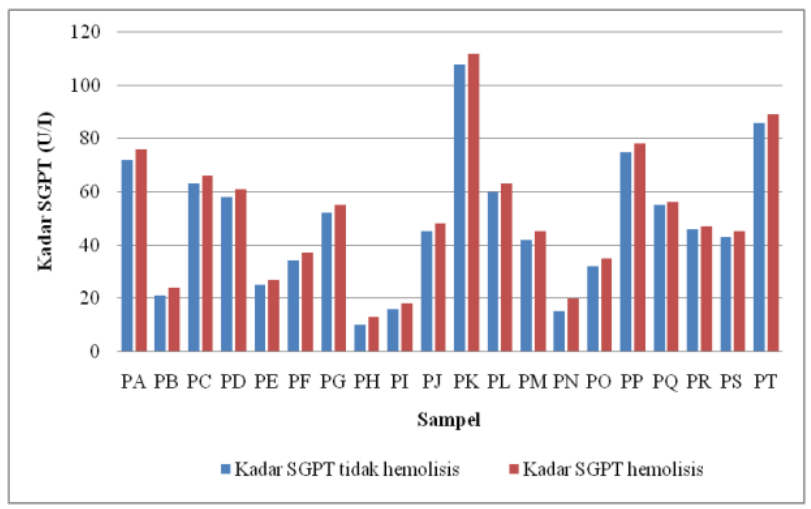

Gambar 1. Diagram Batang Kadar SGPT Tidak Hemolisis dan Kadar SGPT Hemolisis

Berdasarkan pemaparan dari tabel 1., maka secara garis besar dapat ditampilkan deskriptif data penelitian sebagai berikut :

Tabel 2. Deskriptif Data Penelitian

\begin{tabular}{|c|c|c|c|c|c|c|c|c|c|}
\hline \multicolumn{10}{|c|}{ Descriptive Statistics } \\
\hline & $\mathrm{N}$ & Range & Minimum & Maximum & Sum & \multicolumn{2}{|c|}{ Mean } & Std. & Variance \\
\hline & Statistic & Statistic & Statistic & Statistic & Statistic & Statistic & Std. Error & Statistic & Statistic \\
\hline $\begin{array}{l}\text { Kadar SGPT tidak } \\
\text { hemolisis }\end{array}$ & 20 & 98.00 & 10.00 & 108.00 & 958.00 & 47.9000 & 5.67167 & 25.36450 & 643.358 \\
\hline Kadar SGPT hemolisis & 20 & 99.00 & 13.00 & 112.00 & 1015.00 & 50.7500 & 5.70682 & 25.52166 & 651.355 \\
\hline Valid N (listwise) & 20 & & & & & & & & \\
\hline
\end{tabular}

Sumber : Data Penelitian, diolah 
Berdasarkan tabel 2. di atas dapat dijelaskan bahwa jumlah data penelitian (n) untuk kadar SGPT tidak hemolisis sebanyak 20 data penelitian, begitu pula dengan kadar SGPT hemolisis sebanyak 20 data penelitian. Rata - rata (mean) dari data kadar SGPT tidak hemolisis sebesar 47,9 sedangkan rata - rata (mean) dari data kadar SGPT hemolisis adalah 50,75. Jumlah data kadar SGPT tidak hemolisis secara keseluruhan sebesar 958 dan jumlah data kadar SGPT hemolisis adalah sebesar 1015. Dari data tersebut ternyata yang mendapat perlakuan (dilisiskan) terjadi peningkatan $100 \%$ hemolisis.

Pada data penelitian setelah sampel mendapat perlakuan (dilisiskan) didapatkan peningkatan kadar SGPT sebagai berikut :

Tabel 3. Peningkatan Kadar SGPT dari Serum yang Mendapat Perlakuan (dilisiskan)

\begin{tabular}{|c|c|}
\hline $\begin{array}{c}\text { Peningkatan Kadar } \\
\text { SGPT (U/L) }\end{array}$ & $\begin{array}{c}\text { Jumlah atau Prosentase } \\
(\%)\end{array}$ \\
\hline 1 & $2(10 \%)$ \\
\hline 2 & $3(15 \%)$ \\
\hline 3 & $12(60 \%)$ \\
\hline 4 & $2(10 \%)$ \\
\hline 5 & $1(5 \%)$ \\
\hline
\end{tabular}

Berdasarkan tabel 2. dapat diketahui

secara kasar bahwa kadar SGPT hemolisis lebih tinggi daripada kadar SGPT tidak hemolisis. Maka untuk membuktikan lebih terperinci dilakukan uji secara statistik.

\section{Analisis Data}

Data dari hasil penelitian ini terdapat 40 data antara lain 20 data kadar SGPT tidak hemolisis dan 20 data kadar SGPT hemolisis menunjukkan bahwa data dari hasil penelitian ini terdistribusi normal, dengan metode
Kolmogorov Smirnov Test bahwa hasil signifikasinya sebesar 0,995 itu berarti $\mathrm{P}>$ 0,005 sehingga disimpulkan bahwa data penelitian ini terdistribusi dengan normal.

Maka untuk menguji apakah ada pengaruh hemolisis terhadap kadar SGPT dilanjutkan pada uji $\mathrm{t}$ berpasangan. Adapun hasil statistik dengan uji $\mathrm{t}$ berpasangan dapat dilihat pada tabel berikut ini:

Berdasarkan tabel di atas menunjukkan bahwa 20 data kadar SGPT hemolisis lebih besar daripada kadar SGPT tidak hemolisis dari 20 sampel kadar SGPT. Itu berarti bahwa 100\% kadar SGPT tidak hemolisis akan mengalami peningkatan kadar SGPTnya ketika sampel tersebut hemolisis.

Kemudian untuk membuktikan adanya pengaruh hemolisis terhadap kadar SGPT dilakukan uji t berpasangan sebagai berikut :

Hasil dari uji $t$ berpasangan menunjukkan bahwa nilai signifikan 0,00 dengan demikian $\mathrm{P}<0,05$ dapat disimpulkan bahwa terdapat perbedaan antara kadar SGPT tidak hemolisis dengan kadar SGPT hemolisis. Itu berarti dapat disimpulkan juga bahwa ada pengaruh hemolisis terhadap kadar SGPT.

\section{PEMBAHASAN}

Berdasarkan hasil penelitian dan hasil analisa data pada tabel 4.3 didapatkan bahwa rata-rata kadar SGPT tidak hemolisis sebesar 47,9 U/L dan rata-rata kadar SGPT hemolisis sebesar 50,75 U/L. Dari 20 sampel, $100 \%$ 
kadar SGPT hemolisis lebih tinggi dari pada kadar SGPT tidak hemolisis.

Data dari hasil penelitian ini terdapat 40 data antara lain 20 data kadar SGPT tidak hemolisis dan 20 data kadar SGPT hemolisis menunjukkan bahwa data dari hasil penelitian ini terdistribusi normal, dengan metode Kolmogorov Smirnov Test bahwa hasil signifikasinya sebesar 0,995 itu berarti $\mathrm{P}>$ 0,005 sehingga disimpulkan bahwa data penelitian ini terdistribusi dengan normal. Maka, untuk menguji apakah ada pengaruh hemolisis terhadap kadar SGPT dilanjutkan pada uji t berpasangan. Dari hasil uji tersebut menunjukkan bahwa nilai signifikan 0,00 dengan demikian $\mathrm{P}<0,05$ dapat disimpulkan bahwa terdapat perbedaan antara kadar SGPT tidak hemolisis dengan kadar SGPT hemolisis. Itu berarti dapat disimpulkan juga bahwa ada pengaruh hemolisis terhadap kadar SGPT.

Setelah sampel mendapat perlakuan atau dilisiskan, pada hasil penelitian terjadi peningkatan dalam batas normal sebanyak 6 sampel (30\%) dan peningkatan di luar batas normal sebanyak 14 sampel (70\%). Data penelitian yang terjadi peningkatan $1 \mathrm{U} / \mathrm{L}$ sebanyak 2 (10\%), peningkatan $2 \mathrm{U} / \mathrm{L}$ sebanyak 3 (15\%), peningkatan $3 \mathrm{U} / \mathrm{L}$ sebanyak 12 (60\%), peningkatan $4 \mathrm{U} / \mathrm{L}$ sebanyak 2 (10\%), peningkatan $5 \mathrm{U} / \mathrm{L}$ sebanyak 1 (5\%). Dari data penelitian yang mendapat perlakuan ternyata terjadi peningkatan $100 \%$ hemolisis.
Hemolisis merupakan salah satu faktor yang dapat meningkatkan kadar SGPT, karena hemolisis adalah pecahnya membran eritrosit, sehingga hemoglobin bebas ke dalam medium sekelilingnya (plasma). Menurut Riswanto (2010), kerusakan membran sel eritrosit dapat disebabkan oleh antara lain mengeluarkan darah dari spuit tanpa melepas jarum terlebih dahulu. Hal tersebut dapat didukung oleh Anonim a (2008), penambahan larutan hipotonis, hipertonis kedalam darah, penurunan tekanan keras pada permukaan membran eritrosit, zat/unsur kimia tertentu, pemanasan dan pendinginan, rapuh karena ketuaan dalam sirkulasi darah. Apabila sel eritrosit pecah maka akan menyebabkan isi sel keluar, misalnya: enzim, elektrolit dan hemoglobin sehingga tampak merah muda sampai merah pada serum. Pada penelitian ini menggunakan perlakuan pengeluaran darah dari spuit tanpa melepas jarum terlebih dahulu terhadap sampel, sampai menghasilkan darah lisis. Sehingga terdapat kesesuaian antara perlakuan dengan teori.

Pada hemolisis terjadi pemecahan membran eritrosit, sehingga dalam proses tersebut dapat mengeluarkan enzim SGPT yang dalam keadaan normal terdapat dalam eritrosit dan setelah eritrosit mengalami lisis enzim SGPT keluar ke cairan ekstraseluler, sehingga dalam tes laboratorium menunjukkan peningkatan kadar SGPT yang dapat juga mengakibatkan hasil test yang tidak akurat. 
Menurut Le Fever (1997) dan Ekawati (2009), SGPT merupakan enzim yang utama banyak ditemukan pada sel hati serta efektif dalam mendiagnosis destruksi hepatoseluler. Enzim ini dapat dijumpai dalam jumlah kecil pada darah, otot jantung, ginjal dan otot rangka. Ketika sel hati rusak, enzim ini merembes ke dalam aliran darah sehingga menyebabkan kadar SGPT meningkat. Peningkatan kadar enzim dalam darah merupakan akibat adanya kerusakan sel yang mengandung enzim atau adanya perubahan permeabilitas membran sel, sehingga makromolekul - makromolekul dapat menembus dan terlepas ke dalam cairan ekstrasel (Widman, 1989).

Hasil penelitian ini menunjukkan kadar SGPT masih dalam batas normal atau rentang nilai yang tidak seberapa jauh dari keadaan tidak lisis, hal ini disebabkan karena enzim SGPT terutama terdapat di dalam hati. Menurut Ekawati (2009), konsentari SGPT paling banyak ditemukan pada organ hati, selain pada organ tersebut SGPT tidak menunjukkan konsentrasi yang besar sehingga saat dilisiskan diluar dari organ hati kadar atau konsentrasi SGPT berubah dalam kadar yang sedikit.

\section{KESIMPULAN / CONCLUSSION}

Dari hasil penelitian dan pembahasan yang telah dilakukan, maka dapat disimpulkan sebagai berikut :
1. Rata-rata kadar SGPT tidak hemolisis sebesar 47,9 U/L.

2. Sampel yang mendapat perlakuan (dilisiskan) $100 \%$ mengalami hemolisis, dapat dibuktikan dengan adanya peningkatan kadar SGPT.

3. Rata-rata kadar SGPT hemolisis sebesar $50,75 \mathrm{U} / \mathrm{L}$.

4. Peningkatan kadar SGPT dari serum yang mendapat perlakuan (dilisiskan):

a. Peningkatan kadar SGPT $1 \mathrm{U} / \mathrm{L}$ sebanyak $2(10 \%)$.

b. Peningkatan kadar SGPT 2 U/L sebanyak $3(15 \%)$.

c. Peningkatan kadar SGPT 3 U/L sebanyak $12(60 \%)$.

d. Peningkatan kadar SGPT 4 U/Lsebanyak 2 (10\%).

e. Peningkatan kadar SGPT 5 U/L sebanyak $1(5 \%)$.

5. Terjadi peningkatan dalam batas normal sebanyak 6 sampel (30\%) dengan rata-rata sebesar $3 \mathrm{U} / \mathrm{L}$ dan peningkatan diluar batas normal sebanyak 14 sampel (70\%) dengan rata-rata sebesar 2,7 U/L.

6. Terdapat perbedaan antara kadar SGPT tidak hemolisis dengan kadar SGPT hemolisis.

Saran untuk peneliti yang akan datang diharapkan dapat meneliti pengaruh hemolisis terhadap kadar enzim transaminase dan atau parameter fungsi hati lainnya. Hal ini diharapkan untuk menambah pengetahuan bagi para pembaca khususnya tenaga analis. 


\section{DAFTAR PUSTAKA / BIBLIOGRAPHY}

Anonim a. 2008. Hemolisis dan Fragilitas Eritrosit. http//biologi.co.id. Diakses tanggal 17 April 2011.

Anonim b, 2000. Penjelasan Tes Fungsi Hati Tes laboratorium sering kali digunakan untuk memastikan diagnosis. http://www.spiritia.or.id/cst/dok/lft1.pdf . Diakses tanggal 8 mei 2011.

Baradero, Mary. 2008. Klien Gangguan Hati. EGC. Jakarta.

Baron, D. N. 1990. Kapita Selekta Patologi Klinik. Gramedia Pustaka Utama. Jakarta.

Ekawati,Utami.2009.

Hepatoprotektor(Penjaga Hati). Error! Hyperlink reference not valid. Diakses tanggal 17 April 2011.

Ganong, W. F. 2000. Buku Ajar Fisiologi Kedokteran. Gramedia Pustaka Utama. Jakarta.

Guyton, A. C. 1999. Fisiologi Manusia dan Mekanisme Penyakit. Gramedia Pustaka Utama. Jakarta.

Hadi, S. 2006. Penanganan Sampel Pasca Phlebotomy untuk Pemeriksaan Laboratorium. Workshop Phlebotomy FKILK PDS PATKLIN. Surabaya.

Murray, 1999. Biokimia Harper. EGC. jakarta

Kowalak, P. Jennifer. 2009. Buku Pegangan Uji Diagnostik. EGC. Jakarta.

Kosasih, E. N. 2008. Tafsiran Hasil Pemeriksaan Laboratorium Klinik. Karisma. Tangerang.

Le fever, K. J. 1997. Buku Saku Pemeriksaan Laboratorium dan Diagnostik dengan Implikasi Keperawatan. EGC. Jakarta.
Legawa, Cahya. 2011. Tes Fungsi Hati. http://wordpress.org/ Diakses tanggal 8 Mei 2011.

Pearce, E. C. 2004. Anatomi dan Fisiologi untuk Paramedis. Gramedia. Jakarta.

Price, A. S. 2005. Patofisiologi Konsep Klinis Proses-Proses Penyakit. EGC. Jakarta.

Rino, 2006. SGOT - SGPT Sering Bikin Kecele. Wordpress.com. Diakses tanggal 24 Mei 2011.

Riswanto,2010.Phlebotomi.http://Laboratoriu mKesehatan.blogspot.com/Phlebotomi.h tml. Diakses tanggal 12 Juli 2011.

Riyono, 2007. Pengendalian Mutu Laboratorium Kimia Klinik dilihat dari Aspek Mutu Hasil Analisis laboratorium. Jurnal Ekonomi dan Kewirausahaan, Volume 7, nomor 2, halaman 172-187.

Ronald, A. S. 2004. Tinjauan Klinis Hasil Pemeriksaan Laboratorium. Gramedia Pustaka Utama. Jakarta.

Smeltzer, C. S. 2001. Keperawatan Medikal Bedah. EGC. Jakarta.

Syaifuddin. 1997. Anatomi dan Fisiologi Keperawatan. Gramedia Pustaka Utama. Jakarta.

Wales, J. 2011. Enzim, Hemolisis. http//wikipedia.com. Diakses tanggal 5 Mei 2011.

Widman, F.K. 1989. Tinjauan Klinis atas Hasil Pemeriksaan Laboratorium. EGC. Jakarta.

Zainuddin, M. 2000. Metodologi Penelitian. Jakarta. 